\title{
Screening of Indigenous Bacterial Isolates from Dawadawa (African Locust Beans) in North Central Nigeria
}

\author{
Oyetola Moradeke Toyosi ${ }^{1,2,}$, Agarry Olubunmi ${ }^{2}$, Oyetola Simeon $^{3}$ \\ ${ }^{1}$ Department of Health and Biomedical Sciences, Federal Ministry of Science and Technology, Abuja, Nigeria \\ ${ }^{2}$ Department of Microbiology, University of Abuja, Abuja, Nigeria \\ ${ }^{3}$ Department of Animal Science, University of Abuja, Abuja, Nigeria
}

Email address:

omoradeke@yahoo.com (O. M. Toyosi)

${ }^{*}$ Corresponding author

\section{To cite this article:}

Oyetola Moradeke Toyosi, Agarry Olubunmi, Oyetola Simeon. Screening of Indigenous Bacterial Isolates from Dawadawa (African Locust Beans) in North Central Nigeria. Biochemistry and Molecular Biology. Vol. 2, No. 6, 2017, pp. 67-72. doi: 10.11648/j.bmb.20170206.11

Received: September 8, 2017; Accepted: September 23, 2017; Published: November 5, 2017

\begin{abstract}
This study was undertaken to screen for Lactic Acid Bacteria (LAB) from indigenous fermented seeds; dawadawa. Isolation of LAB was carried out on MRS Agar. Biochemical, morphological and physiological examinations according to the Bergeys manual were used to identify the bacterial isolates. Six bacterial strains were obtained and given the designations DN, DO, DJ, DT, DG and DH respectively. The obtained colonies were all capable of fermenting lactose, sucrose, trehalose, glucose, maltose and lactulose as the sole carbon source in the broth. Morphological examination revealed that the isolates obtained were non-spore forming gram positive colonies ranging from creamy to white, clear, cocci and rod shaped, smooth textured and flat elevation with transparent opacity. Their growth profile study revealed that all isolates appeared to be mesophilc with progressive growth patterns observed between 24-96 hours at the same parameters for incubation. Isolates DO and DJ were observed to exhibit the fastest growth as determined by measuring optical density of the cells in broth using spectrophotometer at $550 \mathrm{~nm}$. Conclusions from the observed experiment indicate that isolated LABs from dawadawa could be applied in other probiotics as starter cultures and be improved for other commercial uses.
\end{abstract}

Keywords: Lactic Acid Bacteria, Growth Profile, pH, Salinity

\section{Introduction}

Lactic acid bacteria (LAB) represents a unique group of industrially relevant bacteria, commonly referred to or associated with probiotic bacteria consumed globally in mainly fermented products [1]. This group of gram positive bacteria are easily cultivated from non-milk products including meat, decomposing plant material as well as the gastrointestinal tract whereby they expressly consume and convert these materials, producing lactic acid as the main byproduct [2-3]. New frontiers in biotechnology has led to the appreciation of its robust nature that makes it a safe and effective enzymatic powerhouse towards the production of food additives, pharmaceutical compounds and vaccines [45]. The industrial drive for harnessing more value-added products from $\mathrm{LAB}$ stems from the enhancement of their metabolic properties to the flavour (acetoin, peptides), texture (exopolysaccharide) and general fortification (riboflavin, folate, cobalamin) of the nutritional value of the food product it is applied to [6-10].

The rich gamut of chemically diverse bioactive compounds obtained from LAB suggests that there is a large collection of $\mathrm{LAB}$ in nature for which their existence in our known environments is limited to the region, nature of habitat, temperature, etc. In many African countries, the production of fermentable dairy products does not necessarily include the application of starter cultures, thus suggesting that the fermentation of such products occurs spontaneously from microorganisms emanating from the external environment or the processing equipment [11]. This now advocates for the isolation of a pool of LAB from multiple dairy and non-dairy products towards industrially relevant uses. Factors like the viability of LAB in appreciable quantities within the product is a fundamental requirement for selection. 
Data revealed that the daily diet in Africa is primarily fermented food [12], thus making the consumption of dairy an age-old tradition in countries like Nigeria. Like many other African countries, the different tribes in the country consume a range of other fermentable plant products one of which is the African Locust beans (Parkia biglobosa) known to the northern part of Nigeria as dawadawa or nèrè.

The goal of any of such practices would be the preservation of the processed products thereby preventing spoilage as the latter is common [13]. The most prominent LAB species known within this African region within dairy and fermentable non-dairy food products have been identified as Lactococcus lactis subsp. lactis, Leuconostoc mesenteroides subsp. dextranicum, Lb. curvatus, Leuc. Paramesenteroides and Lb. planturum. In the northern part of Nigeria, dawadawa is the most widely consumed dairy product to the delight of the northern communities [14]. Different strains of lactic acid bacteria are believed to be obtainable from such unique dairy sources [15-16]. The probiotic nature of indigenous dairy products constitutes an integral part of the gastrointestinal flora that boosts host metabolism [17-18]. The aim of this study was to isolate and characterize possible lactic acid bacteria from dairy samples indigenous to northern Nigeria.

\section{Materials and Methods}

\subsection{Isolation of Bacteria}

Fresh samples of dawadawa were collected from Gwagwalada Area Council of Abuja. Each was taken in a sterile container separately and placed in a polyethylene bag during transportation to the laboratory employing standard conditions for sample collection. $1 \mathrm{~g}$ of dawadawa sample (mashed) was weighted aseptically and was suspended in $9 \mathrm{ml}$ of $0.15 \%$ peptone water under aseptic condition and vortexed for proper homogeneity. $1 \mathrm{ml}$ of each thoroughly mixed sample was serially diluted up to $10^{-6}$ and used to inoculate MRS agar plates supplemented with $100 \mathrm{mg} / 1$ cycloheximide. Each plate was incubated at $37^{\circ} \mathrm{C}$ for 48 hours and observed for the growth of colonies. All experiments were carried out in triplicate.

\subsection{Identification by Morphological and Biochemical Assessment}

Visually distinct colonies were randomly selected and streaked repeatedly on antibiotic supplemented MRS agar to obtain pure isolates. The distinct pure isolates were then subjected to morphological identification with the following parameters: Colour, Shape, Texture, Elevation, Margin, Opacity and gram staining [19]. Wet mounts of isolated cell samples were prepared in distilled water and examined using 40X objective magnification. Biochemical characterization performed included catalase, production of gas from glucose, methyl red-voges proskauer (MR-VP) and carbohydrate fermentation using phenol red broth technique. Sugars used to determine the fermentation profile of the isolates were fructose, galactose, lactose, maltose, mannitol, arabinose, trehalose, sucrose and lactulose. The cultures were identified based on the pattern of sugar utilization [20].

\subsection{Effect of $\mathrm{NaCl}$ Concentrations on Growth of Isolates}

The isolates were inoculated in MRS broth having different salt concentration $(4.5 \%, 6.5 \%)$ and incubated at $37^{\circ} \mathrm{C}$ for $24-48$ hours. The culture tubes were observed for the presence or absence of growth. The development of turbidity in culture tubes was recorded as the ability of isolates to grow at the given salt concentration.

\subsection{Effect of pH Concentrations on Growth of Isolates}

Pure isolates were inoculated unto MRS broth media with $\mathrm{pH}$ values of 4.5 and 9.6 using $1 \mathrm{M} \mathrm{NaOH}$ and $1 \mathrm{M} \mathrm{HCl}$ followed by incubation at $37^{\circ} \mathrm{C}$ for 96 hours. Turbidity was monitored periodically ( 24 hours) to determine growth measurements were used to determine growth.

\subsection{Growth Profile Studies}

The isolates were tested for their ability to grow within the mesophilic temperature range in MRS broth for 4 days at 28, 33 and $37^{\circ} \mathrm{C} .10 \mathrm{~mL}$ of MRS broth tubes were inoculated with $1 \%$ of suspected Lactobacilli cultures. Periodic ( 24 hour) measurements of growth was achieved using a UV-VIS spectrophotometer, measurements were taken at $550 \mathrm{~nm}$ to determine their viability [21].

\section{Results and Discussion}

Analysis from the isolation of microorganisms from fresh dawadawa using MRS media revealed that of the six visual distinct colonies obtained, they were 2 white, 2 cream, 1 creamy-white and 1 dark cream coloured colonies. The six bacterial strains were given the designations DN, DO, DJ, DT, DG and DH respectively. Morphological examination of these isolates revealed non-spore forming gram positive rod and cocci shaped colonies ranging from creamy to white, clear and transparent with flat elevation (Table 1). Each pure isolate was observed under (40X) microscope. Several reports revealed that a lot of Lactobacillus bacterial species which have successfully been isolated from dairy products across Africa appeared as both rod and cocci shaped, nonspore forming and gram positive [14], [22-23]. However, their conclusion was asserted via the results of physiological and biochemical analysis, primarily of which is the catalsase test. Just like the studies reported above, this study revealed that all studied isolates were catalase negative, a feature that is synonymous with all known species of Lactobacillus [24].

Another principle feature of LABs would be their ability to produce lactic acid as a metabolic by-product from carbohydrate fermentation which is easily assayed via the consumption of lactate [25]. In this study, the isolated bacteria were all capable of consuming lactose, sucrose, trehalose, glucose, maltose and lactulose as the sole carbon source in the broth (table 2). With the exception of isolates 
DJ and DG respectively, all other isolates displayed the ability to metabolize dextrose and mannitol. These presents a unique means of identification by screening whereby select strains like Lactobacillus bulgaricus from the Lactobacillus family and several from the Leuconostoc family display the same biochemical with the inability to ferment mannitol, physiological and morphological features [25]. Growth optimum studies via $\mathrm{pH}$ variation was undertaken and revealed that maximum growth was attainable between 2-3 days of either acidic or alkaline medium (table 3 ). Analysis of the data obtained indicates growth fluctuations by way of turbidity measurements over time. This addresses the veracity of the cell membrane coupled with the cells acidification activity.

Table 1. Morphological Identification of Obtained Isolates.

\begin{tabular}{|c|c|c|c|c|c|c|c|c|c|}
\hline $\mathbf{S} / \mathbf{N}$ & Isolate & Colour & Shape & Opacity & Transparency & Elevation & Margin & Surface & Gram Reaction \\
\hline 1 & $\mathrm{DN}$ & White & Irregular & Clear & Transparent & Flat & Entire & Smooth & $+\mathrm{ve}$ \\
\hline 2 & DO & Cream & Circular & Clear & Transparent & Convex & Entire & Smooth & + ve \\
\hline 3 & DJ & White & Irregular & Clear & Transparent & Flat & Entire & Smooth & $+\mathrm{ve}$ \\
\hline 4 & DT & Dark Cream & Irregular & Clear & Transparent & Flat & Entire & Dry & $+\mathrm{ve}$ \\
\hline 5 & DG & Creamy & Circular & Clear & Transparent & Flat & Entire & Smooth & + ve \\
\hline 6 & $\mathrm{DH}$ & Creamy-white & Irregular & Clear & Transparent & Flat & Filamentous & Smooth & + ve \\
\hline
\end{tabular}

Key: + ve $=$ Positive.

Table 2. Biochemical Assessment of Obtained Isolates.

\begin{tabular}{|c|c|c|c|c|c|c|c|c|c|c|}
\hline Isolate & Catalase & $\mathrm{CO}_{2}$ Production & Sucrose & Lactose & Trehalose & Dextrose & Glucose & Maltose & Mannitol & Lactulose \\
\hline $\mathrm{DN}$ & -ve & -ve & $+\mathrm{ve}$ & + ve & $+\mathrm{ve}$ & $+\mathrm{ve}$ & $+\mathrm{ve}$ & + ve & + ve & $+\mathrm{ve}$ \\
\hline DO & -ve & + ve & + ve & + ve & + ve & + ve & + ve & $+\mathrm{ve}$ & + ve & + ve \\
\hline DJ & -ve & -ve & $+\mathrm{ve}$ & + ve & + ve & -ve & + ve & + ve & + ve & + ve \\
\hline DT & -ve & +ve & + ve & + ve & + ve & + ve & + ve & + ve & + ve & + ve \\
\hline DG & -ve & + ve & + ve & + ve & + ve & + ve & + ve & $+\mathrm{ve}$ & -ve & $+\mathrm{ve}$ \\
\hline $\mathrm{DH}$ & -ve & -ve & + ve & + ve & + ve & + ve & + ve & $+\mathrm{ve}$ & + ve & + ve \\
\hline
\end{tabular}

Key: + ve $=$ Positive, - ve $=$ Negative.

Table 3. pH Analysis and Growth Profile.

\begin{tabular}{|c|c|c|c|c|c|c|c|c|}
\hline \multirow{2}{*}{ Organism } & \multicolumn{4}{|l|}{ pH 4.5} & \multicolumn{4}{|l|}{ pH 9.6} \\
\hline & $24 \mathrm{Hrs}$ & $48 \mathrm{Hrs}$ & $72 \mathrm{Hrs}$ & 96Hrs & 24Hrs & $48 \mathrm{Hrs}$ & $72 \mathrm{Hrs}$ & 96Hrs \\
\hline $\mathrm{DN}$ & + & ++ & +++ & +++ & + & ++ & +++ & +++ \\
\hline DO & + & ++ & +++ & ++ & + & ++ & +++ & ++ \\
\hline DJ & + & ++ & +++ & +++ & + & ++ & ++ & ++ \\
\hline DT & + & ++ & +++ & +++ & + & +++ & +++ & +++ \\
\hline DG & + & ++ & +++ & ++ & + & +++ & ++ & ++ \\
\hline DH & - & ++ & +++ & +++ & + & ++ & +++ & +++ \\
\hline
\end{tabular}

Key: $+=$ low growth, $-=$ no growth, $++=$ moderate growth, $+++=$ Intensive growth, $-=$ no growth .

The isolated bacteria were subjected to the medium containing two concentrations of salt and monitored daily over a 96-hour incubation period. The level of salinity in an environment is a major factor that triggers an osmotic effect of ions on growth. Generally, highly saline environments perturb normal bacteria cell metabolism whereby the increase in salt concentrations lead to cell death via loss of water. However, via natural evolution and diversity studies, it has been observed that some bacteria species initiate growth only in the presence of high salt concentrations. All six strains in this study could grow in the presence of 4.5 and $6.5 \% \mathrm{NaCl}$ in liquid culture (table 4). The robust physiology of industrially significant lactic acid bacteria towards inhibitory compounds and environmental stress form part of the criteria for selection. In this investigation, growth was monitored in broth cultures containing different concentrations of salt and $\mathrm{pH}$, maintained at $33^{\circ} \mathrm{C}$ over a 96 hour incubatory period (tables 3 and 4). The data obtained suggested that the generation of by-products such as lactic acid could account for the conformational changes towards tolerance to aid in its survival in the presence of such inhibitory agents. To survive under such conditions it is assumed that such lactic acid bacteria would have developed mechanism to maintain adequate intracellular $\mathrm{pH}$ which may include the reorganization of its lipid composition to thwart the effect of such by-products [26-27].

Bacterial growth profile analysis measured at $550 \mathrm{~nm}$ over a 4 day incubatory period at $28^{\circ} \mathrm{C}, 33^{\circ} \mathrm{C}$ and $37^{\circ} \mathrm{C}$ revealed different growth patterns for which all isolates exhibited growth captured by their resulting absorbance values (figures 1-3). Analysis of the growth patterns revealed an almost similar absorbance reading over the three temperatures for which isolate DO and DJ displayed the most prolific rates of growth. Although certain variations were observed between $28-37^{\circ} \mathrm{C}$, the values obtained appeared similar to data obtained from other studies [25], [28-29]. The data also suggests that the isolated microorganisms are all mesophilic as their optimum growth is been 20 and $40^{\circ} \mathrm{C}$. 
Table 4. Effect of Salinity on Bacterial Growth.

\begin{tabular}{|c|c|c|c|c|c|c|c|c|}
\hline \multirow{2}{*}{ Organism } & \multicolumn{4}{|c|}{$4.5 \%$ Conc. $\mathrm{NaCl}$} & \multicolumn{4}{|c|}{$6.5 \%$ Conc. $\mathrm{NaCl}$} \\
\hline & 24Hrs & $48 \mathrm{Hrs}$ & $72 \mathrm{Hrs}$ & 96Hrs & $24 \mathrm{Hrs}$ & $48 \mathrm{Hrs}$ & $72 \mathrm{Hrs}$ & 96Hrs \\
\hline $\mathrm{DN}$ & + & ++ & +++ & +++ & + & ++ & +++ & +++ \\
\hline DO & + & ++ & ++ & +++ & + & ++ & +++ & +++ \\
\hline DJ & + & ++ & +++ & +++ & + & ++ & +++ & +++ \\
\hline DT & + & ++ & +++ & +++ & - & + & ++ & +++ \\
\hline DG & + & ++ & ++ & +++ & + & ++ & +++ & +++ \\
\hline $\mathrm{DH}$ & + & ++ & +++ & +++ & - & + & ++ & +++ \\
\hline
\end{tabular}

Key: + = low growth, - = no growth, $++=$ moderate growth, $+++=$ Intensive growth, $-=$ no growth.

These results appear similar to other studies that have successful isolated and identified different types of lactic acid bacteria from indigenous dairy products across Africa including Lactobacillus raffinolactus, Pediococcus pentosaceus, Lactobacillus Plantarum, Leuconostoc Mesenteroides, Lactobacillus sp., and Lactobacillus acidophilus [31-32].

Growth Profile @ $28^{\circ} \mathrm{C}$

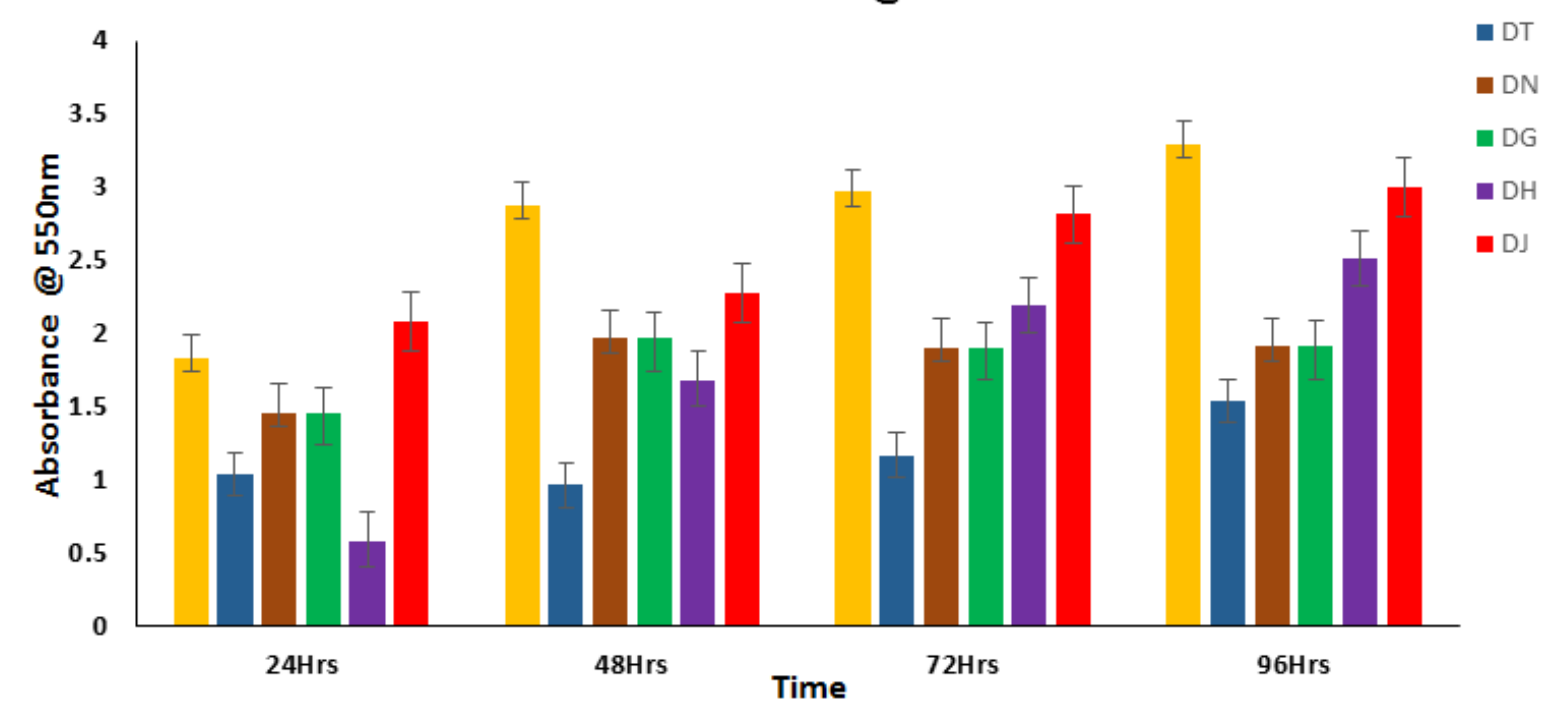

Figure 1. Growth Determination of Bacteria Isolates over Time at $28^{\circ} \mathrm{C}$. Data was obtained from the Mean of Triplicates.

\section{Growth Profile @ 33ํ C}

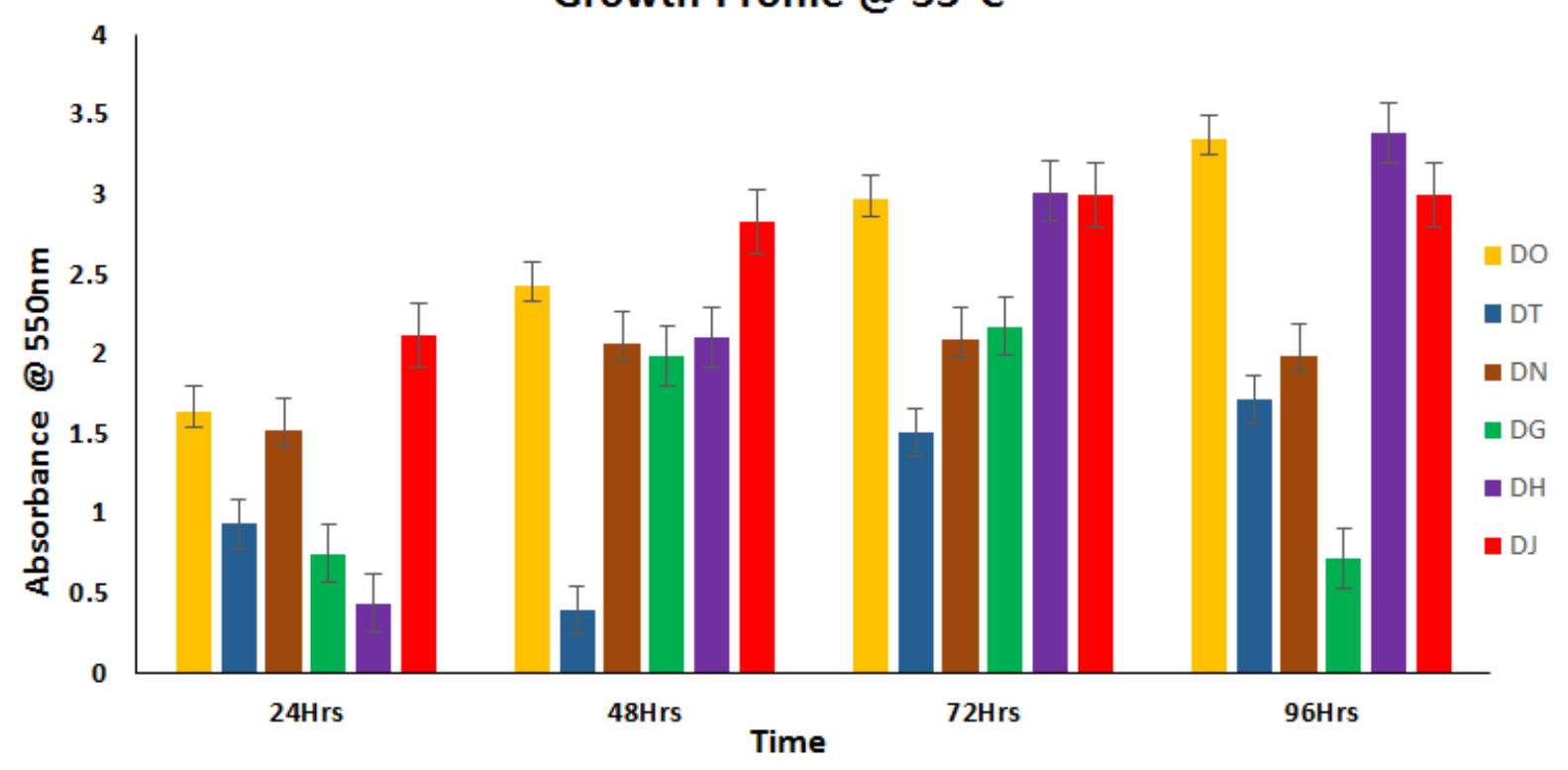

Figure 2. Growth Determination of Bacteria Isolates over Time at $33^{\circ}$ C. Data was obtained from the Mean of Triplicates. 


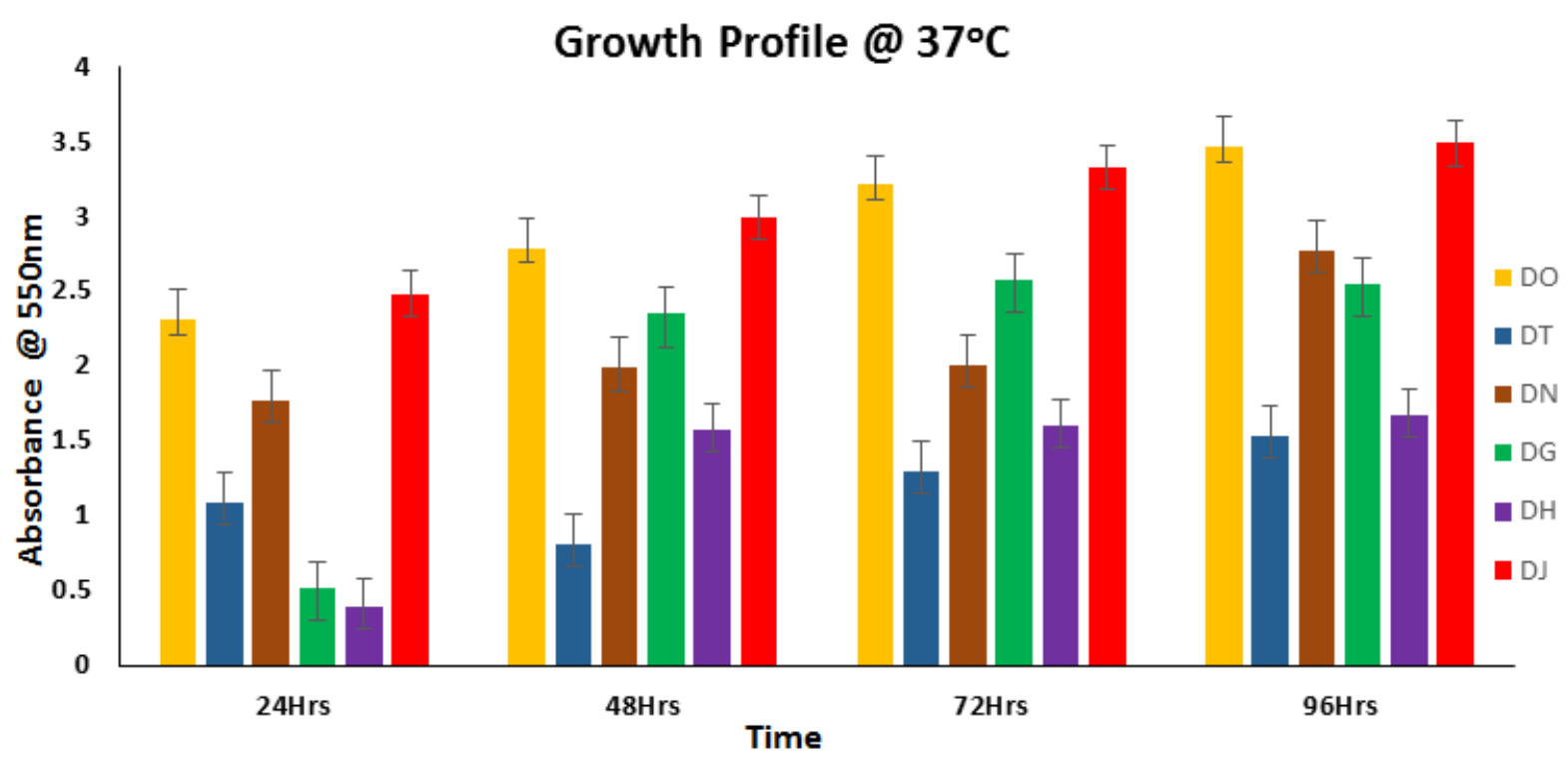

Figure 3. Growth Determination of Bacteria Isolates over Time at $37^{\circ} \mathrm{C}$. Data was obtained from the Mean of Triplicates.

\section{Conclusion}

The overall characteristics of the isolates obtained from dawadawa using MRS media revealed features that are similar to organisms obtained from fermented cow, goat and lamb milk whereby the bacteria all produced acid, were gram positive, catalase negative (Table 1) and capable of survival under microaerophylic conditions [14], [24], [33]. Isolate designated as DO, DT, DN, DG, DH and DJ were all lactic acid fermenters (Table 2) as the predominant characteristic of bacteria obtained from the studied sample. The findings suggest that Lactic acid bacteria are the primary organisms responsible for the fermentation of Parkia biglobosa as these organisms were the only dominant bacteria found on the fermenting seeds. As a consumed product, it is suggestive that the microorganisms obtained maybe manipulated towards probiotic as starter cultures in several food and beverage applications. Other results obtained in this study showed that all isolates obtained could thrive at either side of the $\mathrm{pH}$ spectrum (Table 3 ) as a result of the weakly organic acids they produce or the alkaline biomolecules secreted. The close similarities obtained thus far in present study has revealed the availability of indigenous lactic acid bacteria species that possess tolerance to mildly acidic and mildly alkaline environments, thus confirming data obtained in other studies [34].

\section{References}

[1] Tamang J. P., Wantanbe K., Holzapfel W. H., (2016). Review: Diversity of Microorganisms in Global Fermented Foods and Beverages. Frontiers in Microbiology, 7: 377.

[2] Carr F. J., Chill D., and Maida N., (2002). The lactic acid bacteria: a literature survey. Critical Review Microbiology, 28: 281-370.
[3] de Vos W. M. and Hugenholtz J., (2004). Engineering metabolic highways in lactococci and other lactic acid bacteria. Trends in Biotechnology, 22: 72-79.

[4] Kleerebezem M., and Hugenholtz J., (2003). Metabolic pathway engineering in lactic acid bacteria. Current Opinion in Biotechnology, 14: 232-237.

[5] Hanniffy S., Wiedermann U., Repa A., Mercenier A., Daniel C., Fioramonti J., Tlaskolova H., Kozakova H., Israelsen H., Madsen S., Vrang A., Hols P., Delcour J., Bron P., Kleerebezem M., and Wells J., (2004). Potential and opportunities for use of recombinant lactic acid bacteria in human health. Advances in Applied Microbiology, 56: 1-64.

[6] Boels I. C., van Kranenburg R., Kanning M. W., Chong B. F., de Vos W. M., and Kleerebezem M., (2003). Increased exopolysaccharide production in Lactococcus lactis due to increased levels of expression of the NIZO B40 eps gene cluster. Applied Environmental Microbiology, 69: 50295031 .

[7] Boels I. C., Kleerebezem M., and de Vos W. M., (2003). Engineering of carbon distribution between glycolysis and sugar nucleotide biosynthesis in Lactococcus lactis. Applied Environmental Microbiology, 69: 1129-1135.

[8] Engels W. J. M., Van Hijlckama Vlieg J. E. T., and Smit G., (2003). In Dairy Processing, Improving Quality (ed. Smit, G.) 492-507 (Woodhead Publishing Limited, Cambridge.

[9] Taranto M. P., Vera J. L., Hugenholtz J., de Valdez G. F. and Sesma F., (2003). Lactobacillus reuteri CRL1098 produces cobalamin. Journal of Bacteriology, 185: 5643-5647.

[10] Burgess C., O'Connell-Motherway M., Sybesma W., Hugenholtz J., and van Sinderen D., (2004). Riboflavin production in Lactococcus lactis: potential for in situ production of vitamin-enriched foods. Applied Environmental Microbiology, 70: 5769-5777.

[11] Eyassu S., Araya A., Mohammed Y. K., and Zelalem Y., (2012). Isolation and characterization of lactic acid bacteria from Ititu: Ethiopian traditional fermented camel milk. Journal of Camelid Science, 5: 82-98. 
[12] Jespersen L., (2003). Occurrence and taxonomic characteristics of strains of Saccharomyces cerevisiae predominant in African indigenous fermented foods and beverages. FEMS Yeast Research, 3: 191-200.

[13] Chelule P. K., Mokoena M. P., and Gqaleni N., (2010). Advantages of traditional lactic acid bacteria fermentation of food in Africa. FORMATEX, 1160-1167.

[14] Savadogo A., Quanttara C. A. T., Savadogo P. W., Quatta A. S., Barro N., and Traore A. S., (2004). Microorganisms involved in Fulani Traditional fermented milk in Burkania Faso. Pakistan Journal of Nutrition, 3: 134- 139.

[15] Uzeh R. E., Regina E., and Ayodeji R. K., (2006). Microbiological and Nutritional Qualities of Dairy Products: Nono and Wara. Nature and science, 4: 37-40.

[16] Abeer, A. A., Abdel, A. and Dardir, H. A., (2009). Hygienic Quality of Local Traditional Fermented Skimmed Milk (Laban Rayb) Sold in Egypt: World Journal of Dairy \& Food Sciences, 4(2): 205-209.

[17] Rolfe R. D., (2000). The role of probiotic cultures in the control of gastrointestinal health. Journal of Nutrition, 130: 396-402.

[18] Tuohy K. M., Probert H. M., Smejkal C. W., and Gibson G. R., (2003). Review: Using probiotics and probiotics to improve gut health. Drug Discovery Today, 8: 692-700.

[19] Barnett J. A., Payne R. W., and Yarrow D., (2000). Yeasts: Characteristics and identification. 3rd edn. Cambrie University Press, UK.

[20] Cappuccino J., and Sherman N., (2010). Microbiology: A Laboratory Manual, Pearson Education, Limited, 9.

[21] Younis Y. M. H., and Malik K. M., (2003). TLC and HPLC assays of aflatoxin contamination in Sudanese peanuts and peanut product. Kuwait Journal of Science and Engineering, 30: 79-94.

[22] Tserovska L., Stefano S., and Yordanufa T., (2004). Identification of Lactic Acid Bacteria Isolated from Katyk Goat milk and Cheese. J Cult collection. Bank Industrial Microbiology and Cell Culture, 13: 48-52.

[23] Moulay M., Benlancen K., Aggad H., and Kihal M., (2013). Diversity and Technological Properties of predomonant Lactic Acid Bacteria Isolated from Algerian raw goat milk. Advances in Environmental Biology, 7: 999-1007.

[24] Khalid K., (2011). An overview of Lactic Acid Bacteria. International Journal of Biosciences (IJB), 1: 1-13.
[25] Begum R., Sarker M. S. K., Islam M. A., Alam M. K., and Pramanik M. K., (2017). Isolation and Characterization of Lactic acid Bacteria from Indigenous Dairy Product and Preparation of Starter Culture by Freeze-drying. Bioresearch Communications, 3(1): 304-310.

[26] Magnusson J., and Schnurer J., (2001). Lactobacillus coryniformis subsp. coryniformis strain $\mathrm{Si} 3$ produces a broadspectrum proteinaceous antifungal compound. Applied Environmental Microbiology, 67:1-5.

[27] Magnusson J., Strom K., Roos S., Sjogren J., and Schnurer J., (2003). Broad and complex antifungal activity among environmental isolates of lactic acid bacteria. Fems Microbiology Letters, 219:129-135.

[28] Piano M. D., Morelli L., Strozzi G. P., Allesina S., Barba M., Deidda F., Lorenzini P., Ballare M., Montino F., Orsello M., Sartori M., Garello E., Carmagnola S., Pagliarulo M., and Capurso L., (2006). Probiotics from Research to Consumer. Digestive Liver Disease, 38: 248-255.

[29] Kattcham P. M., Zambou N. F., Tchouan Guep F. M., El soda M., Iqbal M., and Choundary., (2012). Antimicrobial and Safety properties of Lactobacilli Isolate from Two Camerounian Traditional Fermented Foods. Scientia Pharmaceutical, 80: 189-203.

[30] Axelsson L., (2004). Lactic Acid Bacteria: Classification and Physiology. In Lactic Acid Bacteria. Microbiological and Functional Aspects. (S Salminen, A. Von Wright \& a Ouwehand, Eds). New Marcel Dekker, Inc. Pp 1-67.

[31] Beasley S., Tuorila H., and Saris P., (2003). Fermented soymilk with a monoculture of Lactococcus lactis. International Journal of Food Microbiology, 81: 159-162.

[32] Uaboi-Egbenni P. O., Okolie, P. N., Sobande, A. O., Alao, O., Teniola, O., and Bessong P. O., (2009). Identification of subdominant lactic acid bacteria in dawadawa (a soup condiment) and their evolution during laboratory-scale fermentation of Parkia biglobosa (African locust beans). African Journal of Biotechnology, 8: 7241-7248.

[33] Yelnetty A., Purnomo H., Purwadi A., and Mirah A., (2014). Biochemical Characteristics of Lactic Acid Bacteria with Proteolytic Activity and Capability as Starter Culture Isolated From Spontaneous Fermented Local Goat Milk. Journal of Natural Sciences Research, 4: 137-146.

[34] Olajide Adedayo Ajayi (2014). Bacteriology and Qualitative Study of African Locust Bean (Parkia biglobosa). Open Journal of Social Sciences, 2: 73-78. 